\title{
Concentración del virus de la necrosis pancreática infecciosa mediante ultrafiltración de flujo tangencial combinado con filtración de exclusión ${ }^{\#}$
}

\author{
Concentration of infectious pancreatic necrosis virus determined by combining tangential \\ flow filtration with exclusion filtration
}

\section{Chamorro, J C Espinoza, K Soto, J Kuznar}

Laboratorio de Bioquímica y Virología, Instituto de Ciencias Biológicas y Químicas, Facultad de Ciencias, Universidad de Valparaíso, Gran Bretaña 1111, Playa Ancha, Valparaíso, Chile.

\begin{abstract}
SUMMARY
The infectious pancreatic necrosis virus, IPNV, is the etiological agent of a highly contagious disease that affects young salmon. The virus is mostly horizontally transmitted; therefore virus quantitation in water is mandatory for a proper sanitary management in the salmon industry as well as in the environment close to the hatcheries. To evaluate the water as a risk factor for IPNV infection in cultured or wild animals, it is necessary to titrate the virus with a suitable sensitivity. Therefore, a methodology that allows IPNV concentration to be determined in water using two kinds of ultrafiltration was developed. One, based on the tangential flow of the sample along the surface of a membrane, the other based on the retention of the viral particles at the surface of membranes with controlled pore diameter. Reagents and conditions were selected to reduce virus inactivation and/or virus binding to the filters. Finally, a protocol was developed that allows the concentration of IPNV in three orders of magnitude and with a total recovery of infectivity to be determined. This method can be performed in less than one day including virus titration using the fluorescent foci method
\end{abstract}

Palabras clave: Virus IPN, concentración, ultrafiltración.

Key words: IPN virus, concentration, ultrafiltration.

\section{INTRODUCCION}

El virus de la necrosis pancreática infecciosa (virus IPN) es considerado como el virus de especies salmonídeas más prevalente en el mundo. Es el agente responsable de la necrosis pancreática infecciosa (IPN), enfermedad que es una de las principales patologías a las que se ha visto enfrentada la salmonicultura nacional y mundial en los últimos 10 años. Según datos recientes, los brotes del virus IPN en el país afectaron al $48 \%$ del total de las pisciculturas, al $61 \%$ de los centros de esmoltificación y al 49\% de los centros de engorda en 1999 (FIP 2003) provocando enormes pérdidas al sector.

El virus IPN causa una infección sistémica aguda en alevines de 1 a 6 meses de edad, pudiendo provocar, incluso, mortalidades acumulativas del orden del $100 \%$ de la población afectada. Los peces sobrevivientes permanecen en estado portador de por vida, diseminando el virus por largo tiempo, manteniendo así el virus en el agua (Wolf 1988).

Aceptado: 12.07.2005

\# Financiamiento: DIPUV-TEC 2002.
El virus IPN puede ser detectado y/o cuantificado a través de su actividad biológica o como entidad física. Esto último detectando partículas o moléculas virales mediante técnicas como RT-PCR (Rodríguez Saint-Jean 2001) o Western blot (Eliasson 2003a). La actividad biológica del virus se establece a través de sus efectos sobre células de cultivo. En sus formas más prácticas de aplicación, estos métodos tienen un límite de sensibilidad próximo a $10^{4}$ partículas/l.

Sólo la detección del virus activo causante de la necrosis pancreática infecciosa puede indicar el verdadero nivel de riesgo para una piscicultura. Las técnicas empleadas con este propósito suelen ser lentas en su aplicación, sin embargo, recientemente se desarrolló una técnica que permite titular al virus IPN en menos de $20 \mathrm{~h}$. La metodología se basa en la visualización mediante microscopia de epifluorescencia (MEF) de la amplificación del virus en células CHSE-214. Las células infectadas (fluorescencia positiva) son cuantificadas como Focos Fluorescentes (FF) de forma equivalente a la técnica de unidades formadoras de placas (Espinoza y Kuznar 2002).

Para desarrollar la enfermedad un animal debe estar expuesto a una concentración mínima de virus; en principio, para el virus IPN, ésta debiera ser sobre $1 \times 10^{2} \mathrm{UFP} / 1$ 
(Wolf 1988). Sin embargo, la sensibilidad de las técnicas anteriormente señaladas es del orden de $1 \times 10^{4} \mathrm{UFP} / 1$. Consecuentemente, para cuantificar virus, desde el agua, en el rango de riesgo antes mencionado es preciso concentrarlo antes de titularlo.

En el caso específico del virus IPN se han descrito procedimientos de concentración basados en distintos principios. Se han descrito métodos de extracción en polímeros de dos fases (Cohen 1973, Tu 1974, Grinnel y Leong 1979), metodologías basadas en la adsorciónelusión del virus (Eliasson y col., 2003b) y procedimientos de ultrafiltración, tanto sobre filtros de membrana cargados positivamente (Maheshkumar y col 1991a, 1991b, 1992, McAllister y Bebak 1997) como mediante la utilización de la ultrafiltración de flujo tangencial (UFT) (Watanabe 1988).

En los últimos años se han desarrollado numerosas técnicas en los ámbitos de las microbiologías marina, ecológica y humana para el monitoreo de virus en ambientes acuáticos. En éstas los virus se retienen en filtros con un diámetro de poro inferior al del tamaño del virus, tras lo cual, las partículas se marcan con sondas fluorescentes (Noble 2001). Considerando que la retención de los microorganismos sobre el filtro implica en sí mismo un procedimiento de concentración, se decidió explorar si el virus IPN puede se retenido y recuperado desde tales filtros.

El propósito de este trabajo es el de utilizar la combinación de dos procedimientos de ultrafiltración, el de flujo tangencial y el de retención en membranas de poro controlado. Así se logra concentrar y cuantificar al virus IPN en muestras de agua generando una herramienta para el monitoreo rutinario de aguas en las pisciculturas y/o en ambientes vecinos a ellas.

\section{MATERIALES Y METODOS}

Células y virus. Se emplearon células CHSE-214 (ATCC CRL 1681) mantenidas a $20^{\circ} \mathrm{C}$ en Medio Mínimo Esencial (MEM), suplementado con sales de Earles, l-glutamina $2 \mathrm{mM}$, aminoácidos no esenciales $0.1 \mathrm{mM}$ (Gibco EE.UU.), bicarbonato de sodio $(2 \mathrm{mg} / \mathrm{ml})$, gentamicina $(50 \mu \mathrm{g} / \mathrm{ml})$ y $10 \%$ de suero fetal bovino (SFB) (Invitrogen EE.UU.). Para realizar los análisis de inmunofluorescencia las células se cultivaron a $20{ }^{\circ} \mathrm{C}$ sobre cubreobjetos de vidrio de $12 \mathrm{~mm}$ de diámetro en microplacas de plástico de 24 pocillos o en placas Petri de $35 \mathrm{~mm}$ de diámetro.

El virus utilizado fue aislado y caracterizado en Chile y es idéntico al serotipo VR-299 (Espinoza y col 1985).

Cuantificación de virus IPN mediante focos fluorescentes $(F F)$. Este método fue descrito por Espinoza y Kuznar (2002) y se utilizó para determinar los títulos virales. La titulación se realizó preparando diluciones seriadas en MEM con 2\% SFB. Alícuotas de $10 \mu 1$ se inocularon so- bre monocapas preconfluentes de células CHSE-214 cultivadas en cubreobjetos de vidrio. Tras $1 \mathrm{~h}$ de adsorción a $20{ }^{\circ} \mathrm{C}$, el medio fue reemplazado por $1 \mathrm{ml}$ de medio fresco suplementado con $2 \%$ de SFB.

Tras $16 \mathrm{~h}$ el medio fue removido y las células fueron fijadas con metanol a $-20{ }^{\circ} \mathrm{C}$ durante $10 \mathrm{~min}$. Posteriormente fueron lavadas con buffer fosfato salino $\mathrm{PBS}$ ( $\mathrm{NaCl} 137 \mathrm{mM}$; KCl $2.7 \mathrm{mM}$; $\mathrm{KH}_{2} \mathrm{PO}_{4} 1.5 \mathrm{mM}$; $\left.\mathrm{Na}_{2} \mathrm{HPO}_{4} 8 \mathrm{mM}\right)$ e incubadas con anticuerpo monoclonal (Am14) anti VP2 $(1 \mu \mathrm{g} / \mathrm{ml})$ durante $1 \mathrm{~h}$ a temperatura ambiente (TA). Las células fueron nuevamente lavadas con PBS e incubadas con anticuerpo secundario antirratón conjugado con FITC (Sigma EE.UU.), 1/100 en PBS, por 30 minutos a TA. Luego de la incubación, las células fueron lavadas tres veces por 5 min con PBS y montadas con solución de montaje (Dako, Dinamarca). Las muestras teñidas fueron examinadas mediante un microscopio de epifluorescencia (Olympus BX60) con objetivo 10x.

Concentración del virus IPN por ultrafiltración de flujo tangencial (UFT). El método consiste en la constante recirculación de la muestra a través de un filtro (Cartucho Prep/scale, Millipore, EE.UU.) de éster de celulosa, con un área de $0,093 \mathrm{~m}^{2}\left(1 \mathrm{ft}^{2}\right)$ y con un límite de exclusión de $300 \mathrm{kDa}$. Con una bomba peristáltica (Millipore, EE.UU.) se genera una presión de $100 \mathrm{kPa}$ y un flujo de 3-13 1/min. Los compuestos con peso molecular (PM) inferior al tamaño de exclusión pasan a través del filtro y constituyen el "filtrado", mientras que las partículas con PM superior, como es el virus IPN, recirculan generando el volumen "retenido".

Las muestras utilizadas para la experimentación fueron preparadas con $100 \mu \mathrm{l}$ de un inóculo viral de título variable (ver en resultados) diluido en 2 litros de PBS, preparado con agua calidad MilliQ (Quantum ${ }^{\mathrm{tm}}$ Ex Catridge. Millipore, EE.UU.). Este volumen fue recirculado en el sistema de UFT (figura 1) hasta obtener un volumen final retenido de $50 \mathrm{ml}$. Con el objetivo de aumentar el porcentaje de recuperación del virus IPN, se evaluó la variación de éste frente a la adición de SFB al $0,1 \%$ como estabilizador en dos condiciones, adicionándolos a los 2 litros iniciales y cuando el volumen retenido alcanzaba los $500 \mathrm{ml}$. Además, se ensayaron los efectos del extracto de carne (EC) (Difco, EE.UU.) y la albúmina sérica bovina (BSA) (Merck, Alemania), a diversas concentraciones (cuadro 1), como bloqueadores del filtro para disminuir la adsorción del virus.

En todos los experimentos se determinó el título viral del volumen inicial (2 1), del volumen concentrado (50 $\mathrm{ml}$ ) (cuadro 1) y del volumen correspondiente al filtrado (datos no mostrados).

Elusión del virus IPN desde el filtro. Con el propósito de recuperar el virus retenido sobre el filtro, se analizaron dos soluciones como eluyentes: glicina (Amresco, 
EE.UU.) 0,05 M, ajustada a $\mathrm{pH} 7 \mathrm{y}$ pirofosfato de sodio (Sigma, EE.UU.) $100 \mathrm{mM}$, ajustado a pH 10. En ambos casos, la solución de elusión fue mantenida en recirculación por $10 \mathrm{~min}$.

Concentración del virus IPN desde membranas de poro controlado. El filtro Anodisc (Whatman, Inglaterra) utilizado en este trabajo es de óxido de aluminio, con un diámetro de $25 \mathrm{~mm}$ y un tamaño de poro de $0,02 \mu \mathrm{m}$. Con este tamaño se garantiza la retención del virus IPN, cuyo tamaño es de $0,06 \mu \mathrm{m}$. Se ensayó el efecto del SFB $(0,5 \%)$ como estabilizador en muestras de $10 \mathrm{ml}$ de suspensión de virus IPN en PBS, las que fueron filtradas utilizando una bomba de vacío (Motor Electromotors Ltd., EE.UU.). Para recuperar el virus retenido en la superficie del filtro, éste fue lavado con $0,3 \mathrm{ml}$ de solución de elusión durante $5 \mathrm{~min}$. Como eluyentes se ensayaron EC $(1,5 \%)$, SFB $(1,0 \%)$ y pirofosfato de sodio $(10 \mathrm{mM})$. Se evaluó, además, el efecto del EC $(1,5 \%)$ y SFB $(1,0 \%)$ como agentes bloqueadores del filtro; en ambos casos se utilizó un volumen de $0,5 \mathrm{ml}$ que fue incubado por $1 \mathrm{~h}$ sobre el filtro Anodisc. Se determinaron los títulos virales de las muestras iniciales $(10 \mathrm{ml})$ y del volumen de elusión $(0,3 \mathrm{ml})$ mediante la técnica de FF (cuadro 3$)$.

Concentración de virus IPN mediante el método combinado de las ultrafiltraciones de flujo tangencial y poro controlado. Muestras de 2 litros de una solución de virus IPN $\left(3 \times 10^{3} \mathrm{FF} / \mathrm{ml}\right)$ en PBS fueron estabilizadas con SFB $0,5 \%$ y sometidas a UFT hasta obtener un volumen retenido de $50 \mathrm{ml}$. Posteriormente, con el objetivo de eluir el virus adsorbido al filtro, $100 \mathrm{ml}$ de una solución de pirofosfato de sodio $100 \mathrm{mM}$ ajustado a $\mathrm{pH} 10$ fueron mantenidos en recirculación (circuito 1, figura 1) durante $10 \mathrm{~min}$. Se filtraron $10 \mathrm{ml}$ del volumen de elusión a través de filtros de membrana Anodisc, previamente bloqueados con solución de SFB 1\%. El virus retenido fue eluido desde cada filtro con $0,3 \mathrm{ml}$ de una solución de pirofosfato de sodio $10 \mathrm{mM}$. Se determinó el título viral del volumen inicial $(2 \mathrm{l}) \mathrm{y}$ del eluido final $(3 \mathrm{ml}) \mathrm{me}-$ diante la técnica de los FF (cuadro 4).

\section{RESULTADOS Y DISCUSION}

El virus IPN se disemina desde un pez enfermo o desde un portador aparentemente sano, a otros peces, a otras instalaciones de una piscicultura o al medio ambiente, principalmente a través del agua. Por esta razón es importante disponer de métodos simples, económicos y reproducibles para medir la cantidad del virus en el agua.

En principio parece razonable considerar que concentraciones superiores a las 100 UFP/l pueden ser de riesgo epidemiológico. Esta concentración o inferiores a ella parecen ser insuficientes para que un pez desarrolle la enfermedad aguda (Wolf 1988). Por lo tanto, es razona- ble, asimismo, que los métodos que se apliquen a muestras de agua tengan como mínimo la capacidad de detectar estos niveles de virus IPN. Para ello es preciso concentrar al virus antes de titularlo.

Con este propósito es que se ensayaron técnicas que pueden ser aplicadas a volúmenes de agua cuyo manejo rutinario no sea engorroso, esto es, no más allá de 51 . Ensayamos dos metodologías de ultrafiltración: por flujo tangencial (UFT) y por retención en membranas de poro controlado (Anodisc). Cabe señalar que la literatura científica no registra el uso de este tipo de membranas para el virus IPN. Consecuentemente fue necesario optimizar las condiciones de ensayo para estos equipos, por ello es que se incluyeron, además, algunos resultados negativos para facilitar la labor de futuros usuarios o investigadores.

Para cuantificar los viriones capaces de infectar productivamente a células sensibles al virus, se escogió titularlo mediante epifluorescencia utilizando un método de diagnóstico recientemente optimizado (Espinoza y Kuznar, 2002).

Al concentrar virus IPN mediante UFT, según el diseño de la instalación de la figura 1 , se observó que aunque se redujo el volumen inicial en veinte veces, sólo se obtuvo un incremento de la concentración del virus en un factor apenas superior a dos (cuadro 1).

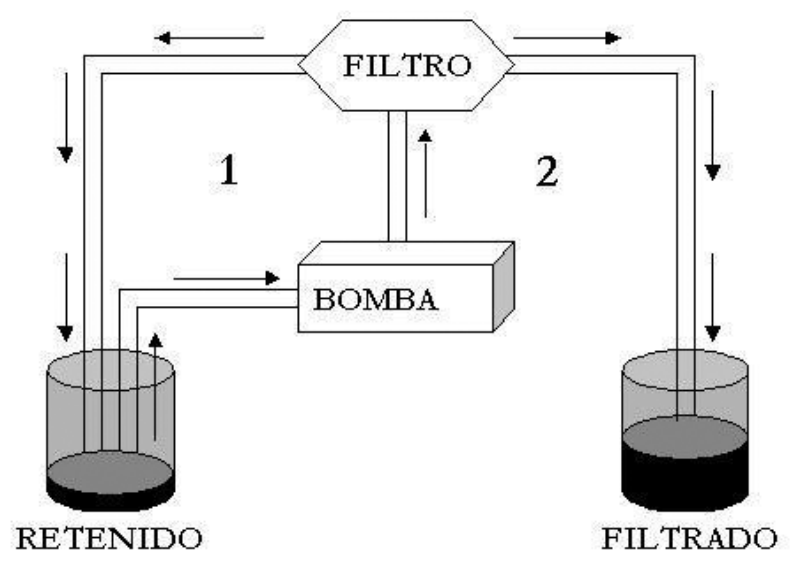

Figura 1. Sistema de UFT utilizado para concentrar virus IPN. La muestra conteniendo al virus es dirigida a través de la bomba peristáltica hacia el filtro de flujo tangencial desde donde la muestra es separada en dos fracciones: la que contiene las partículas excluidas por el filtro (retenido, circuito 1) y la que origina el volumen filtrado a través del filtro (2). El volumen de este último va aumentando durante el procedimiento.

Tangential flow filtration system to determine IPNV concentration. The sample containing the virus is directed towards the filter using a peristaltic pump, the liquid is separated into two fractions: one containing the particles whose sizes are excluded by the filter (retentate, circuit 1) and the other which collects the volume passed trough the filter (filtrate, 2). The volume of these latter increases during the procedure. 
Para incrementar la recuperación viral se evaluó el efecto de la adición de proteínas para minimizar la adsorción inespecífica del virus al filtro y/o para estabilizar su actividad en la suspensión. Sorprendentemente, ninguno de los tratamientos ni las proteínas ensayadas tuvo un significativo impacto en la recuperación del virus y por ende en la concentración de éste desde el agua (cuadro 1).

El virus IPN tiene una considerable resistencia a permanecer activo en diferentes condiciones ambientales, lo cual sugiere que los resultados obtenidos no están relacionados con una pérdida de la actividad del virus producto del procedimiento de ultrafiltración.

Se ensayaron diferentes reactivos que suelen favorecer la elusión de material biológico adsorbido a diferentes tipos de membranas. Tal es el caso del pirofosfato de sodio que ha sido utilizado exitosamente para eluir virus marinos desde muestras de sedimento (Danovaro y col., 2001).

Se obtuvieron recuperaciones virales desde 18 hasta $100 \%$ lavando las membranas con soluciones de glicina o pirofosfato de sodio (cuadro 2). Este último valor se obtiene incorporando SFB 0,5\% a la mezcla inicial y efectuando el lavado con pirofosfato de sodio $100 \mathrm{mM}$.

El aumento en la recuperación viral que se logró al utilizar SFB 0,5\% agregado como estabilizante desde el inicio de la ultrafiltración concuerda con los resultados obtenidos por Watanabe (1988), quien duplicó la recuperación de virus IPN al agregar SFB 0,1\% en muestras filtradas por UFT.

Cuadro 1. Recuperación del virus IPN después de la concentración mediante UFT. Volumen final del concentrado $50 \mathrm{ml}$, $\mathrm{n}=3$.

Recovery of IPN virus after tangential flow ultrafiltration. Final volume of the concentrate $50 \mathrm{ml}, \mathrm{n}=3$.

\begin{tabular}{|c|c|c|c|}
\hline Tratamiento & $\begin{array}{l}\text { Título inicial } \\
(\mathrm{FF} / \mathrm{ml})(2 \mathrm{l})\end{array}$ & $\begin{array}{c}\text { Título final } \\
(\mathrm{FF} / \mathrm{ml})(50 \mathrm{ml})\end{array}$ & $\begin{array}{c}\text { Recuperación } \\
(\%)\end{array}$ \\
\hline $\mathrm{S} / \mathrm{T}$ & $3,3 \times 10^{3}$ & $7,0 \times 10^{3}$ & 6,0 \\
\hline \multicolumn{4}{|c|}{ Bloqueo del filtro } \\
\hline EC $1,5 \%$ & $2,4 \times 10^{3}$ & $1,7 \times 10^{3}$ & 1,7 \\
\hline EC $5,0 \%$ & $2,4 \times 10^{3}$ & $1,8 \times 10^{3}$ & 1,8 \\
\hline SFB $1,0 \%$ & $2,4 \times 10^{3}$ & $2,5 \times 10^{3}$ & 2,7 \\
\hline SFB $5,0 \%$ & $2,4 \times 10^{3}$ & $1,8 \times 10^{3}$ & 1,8 \\
\hline BSA $5,0 \%$ & $2,4 \times 10^{3}$ & $1,7 \times 10^{3}$ & 1,7 \\
\hline \multicolumn{4}{|c|}{$\begin{array}{l}\text { Estabilizante } \\
\text { (SFB 0,5\%) }\end{array}$} \\
\hline $2000 \mathrm{ml}$ & $9,8 \times 10^{3}$ & $4,1 \times 10^{3}$ & 1,1 \\
\hline $500 \mathrm{ml}$ & $1,4 \times 10^{3}$ & $3,2 \times 10^{3}$ & 6,0 \\
\hline
\end{tabular}

Estabilizante

(SFB $0,5 \%)$

$500 \mathrm{ml}$

+ Bloqueo

del filtro

\begin{tabular}{llll} 
SFB $1,0 \%$ & $3,7 \times 10^{3}$ & $6,3 \times 10^{3}$ & 0,4 \\
EC $1,5 \%$ & $3,7 \times 10^{3}$ & $4,0 \times 10^{3}$ & 0,3 \\
\hline
\end{tabular}

Tal como lo muestra el cuadro 3, el mejor eluyente es el pirofosfato de sodio $10 \mathrm{mM}$, lográndose una recuperación viral de un $79 \%$. Más aún, el rendimiento llega al $100 \%$ si se agrega SFB 1\% a la solución inicial y se bloquea previamente el filtro con la misma solución proteica.

Ambos métodos, UFT y retención en filtro Anodisc, fueron acoplados con el propósito de lograr un mayor factor de concentración de la muestra. Tras aplicar los procedimientos sucesivamente se logró reducir el volumen de líquido en 660 veces con una recuperación de las partículas virales del $100 \%$ (cuadro 4). Esto indica que es posible detectar una concentración de 20-30 FF/1 de agua. La sensibilidad de la técnica de detección de FF depende en parte del volumen de inóculo que se deposita

Cuadro 2. Recuperación del virus tras la elusión desde el filtro de UFT, $n=3$.

Virus recovery after elution from tangential flow ultrafiltration filter, $\mathrm{n}=3$.

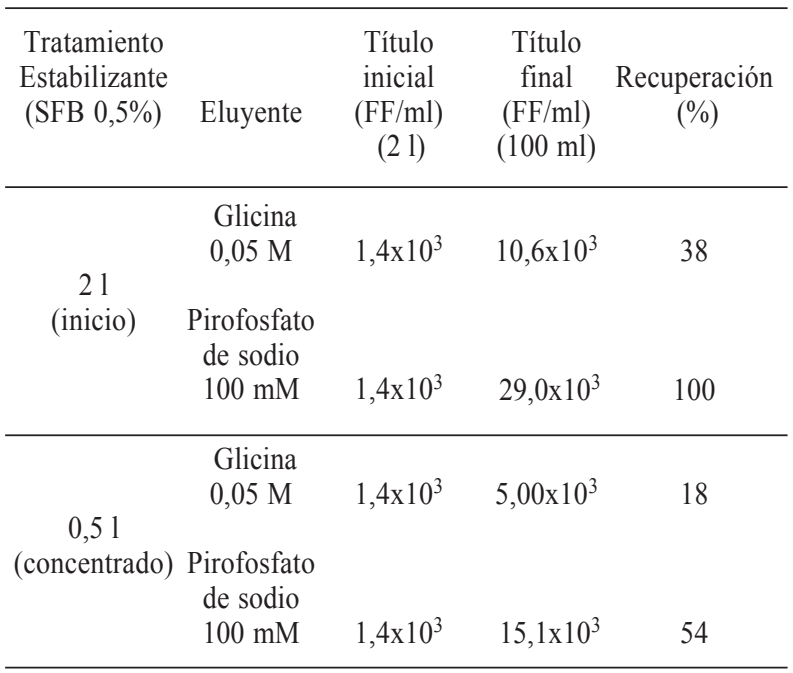

Cuadro 3. Recuperación del virus tras elusión desde el filtro de membrana Anodisc, $n=3$.

$\mathrm{n}=3$.

Virus recovery after elution from the Anodisc membrane,

\begin{tabular}{|c|c|c|c|c|}
\hline Tratamiento & $\begin{array}{c}\text { Eluyente } \\
(0,3 \mathrm{ml})\end{array}$ & $\begin{array}{c}\text { Título } \\
\text { inicial } \\
(\mathrm{FF} / \mathrm{ml}) \\
(10 \mathrm{ml})\end{array}$ & $\begin{array}{c}\text { Título } \\
\text { final } \\
(\mathrm{FF} / \mathrm{ml}) \\
(0,3 \mathrm{ml})\end{array}$ & $\begin{array}{c}\text { Recuperación } \\
(\%)\end{array}$ \\
\hline $\mathrm{S} / \mathrm{T}$ & $\begin{array}{c}\text { SFB 1\% } \\
\text { EC } 1,5 \% \\
\text { Pirofosfato } \\
\text { de sodio } 10 \mathrm{mM}\end{array}$ & $\begin{array}{l}3,8 \times 10^{3} \\
3,8 \times 10^{3} \\
3,8 \times 10^{3}\end{array}$ & $\begin{array}{l}3,9 \times 10^{4} \\
5,1 \times 10^{4} \\
8,2 \times 10^{4}\end{array}$ & $\begin{array}{l}37 \\
49\end{array}$ \\
\hline $\begin{array}{c}\text { Estabilizante } \\
(\text { SFB } 1 \%) \\
+ \\
\text { Bloqueo del } \\
\text { filtro (SFB 1\%) }\end{array}$ & $\begin{array}{l}\text { EC } 1,5 \% \\
\text { Pirofosfato de } \\
\text { sodio } 10 \mathrm{mM}\end{array}$ & $\begin{array}{l}3,8 \times 10^{3} \\
3,8 \times 10^{3}\end{array}$ & $\begin{array}{l}4,0 \times 10^{4} \\
4,0 \times 10^{4}\end{array}$ & $\begin{array}{l}31 \\
33\end{array}$ \\
\hline
\end{tabular}


Cuadro 4. Concentración de virus IPN mediante la combinación de UFT y filtración en membrana Anodisc, $n=3$.

IPN virus concentration combining tangential flow ultrafiltration with Anodisc membrane filtration, $n=3$.

\begin{tabular}{cccccc}
\hline Etapa & $\begin{array}{c}\text { Volumen } \\
\text { inicial } \\
(\mathrm{ml})\end{array}$ & $\begin{array}{c}\text { Título } \\
\text { inicial } \\
(\mathrm{FF} / \mathrm{ml})\end{array}$ & $\begin{array}{c}\text { Volumen } \\
\text { final } \\
(\mathrm{ml})\end{array}$ & $\begin{array}{c}\text { Título } \\
\text { final } \\
(\mathrm{FF} / \mathrm{ml})\end{array}$ & $\begin{array}{c}\text { Recuperación } \\
(\%)\end{array}$ \\
\hline UFT & 2000 & $3,0 \times 10^{3}$ & 100 & $6,2 \times 10^{6}$ & 100 \\
Filtro & & & & & \\
Anodisc & 100 & $2,1 \times 10^{6}$ & 3 & $7,1 \times 10^{7}$ & 100 \\
\hline
\end{tabular}

sobre una determinada área de cultivo celular. Como base de cálculo se puede considerar un volumen de $50 \mu \mathrm{l}$ de inóculo sobre un vidrio de $12 \mathrm{~mm}$ de diámetro cubierto con una monocapa de células CHSE-214 preconfluentes.

En principio es posible cuantificar virus IPN desde unos $20 \mathrm{FF} / \mathrm{ml}$. La sensibilidad del método se puede aumentar, en caso necesario, reduciendo el volumen del eluyente en la etapa de filtración por Anodisc y/o aumentando el volumen de suspensión viral que se aplica al mismo filtro. Esto último fue aplicado en el análisis de muestras de campo enviadas por una empresa productora de salmones que presentaba problemas de infección en sus peces por virus IPN. Estas muestras provenían de sectores en los cuales se había detectado o no la presencia de animales enfermos. El resultado fue coherente con lo que se esperaba y solamente una muestra resultó positiva y con un título de $3,2 \times 10^{2} \mathrm{FF} / 1$ (resultados no mostrados).

La técnica más ampliamente utilizada para concentrar virus desde muestras de agua ha sido la de adsorción y elusión desde filtros que permiten el paso de volúmenes variables $(0,05-2001)$ desde cuyas superficies el virus es resuspendido en volúmenes menores (McAllister y Bebak 1997, Watanabe 1988, Maheshkumar y col 1991a y b, Maheshkumar 1992).

En estas técnicas la eficiencia de adsorción del virus al filtro varía dependiendo principalmente de las características del virus. También es afectada por las características del agua, como el $\mathrm{pH}$, salinidad, niveles de materia orgánica disuelta y el volumen filtrado (New Mexico Water Research Resources Institute 2001).

La UFT es independiente de estos factores (Alonso y col 1999), ya que no depende de la adsorción del virus al filtro, puesto que el virus es retenido por exclusión de tamaño. Sin embargo, en los experimentos realizados se detectaron pérdidas en la recuperación viral producto de la adsorción al filtro, problema que se resuelve con un proceso de elusión que permite, de hecho, obtener prácticamente casi la totalidad del virus en esta nueva fracción. En consecuencia, para garantizar la máxima recuperación de virus, se propone ajustar el líquido con material concentrado (los $50 \mathrm{ml}$ con una pequeña fracción del virus total), a las condiciones necesarias para eluir al resto del virus retenido en la membrana. Esto agregando pirofosfato de sodio y SFB en las condiciones que generaron los resultados del cuadro 2. Así se obtiene un eluyente, preparado en base al volumen retenido, que se hace recircular para recuperar todo el virus (circuito 2, figura 1).

Si bien las técnicas de adsorción-elusión desde filtros permiten el paso de grandes volúmenes de agua, hasta 2001 (Maheshkumar y col 1991a) debe considerarse que los filtros actúan electrostáticamente para atrapar el virus sobre filtros con diámetro de poro de $0,45 \mu \mathrm{m}$, proceso que necesariamente implica pérdidas de virus que pasan a través del poro sin ser retenidos por las cargas de la membrana.

La técnica aquí propuesta retiene las partículas virales por tamaño, privilegiando el aumento del porcentaje de recuperación del virus por sobre el volumen de muestra filtrado. De esta forma se logró minimizar los inconvenientes que genera el transporte de muestras desde los centros de cultivo hasta el laboratorio de análisis.

La industria salmonicultora tendrá la obligación, cada vez mayor, de trabajar con los más altos estándares sanitarios para continuar siendo competitiva en los mercados internacionales. En este sentido, este sector deberá realizar enormes esfuerzos para reducir al máximo el impacto de las enfermedades, las que producen pérdidas, ya sea por menores crecimientos, por disminución de la eficiencia productiva y por mortalidad de los individuos. Adicionalmente, el desarrollo progresivo de esta industria implicará riesgos crecientes para el entorno. Los agentes infecciosos que se producen masivamente en el ámbito de la salmonicultura deben ser una constante preocupación ambiental. La metodología presentada en este trabajo pretende aportar, en el ámbito de la vigilancia de una de estas amenazas, una herramienta para facilitar el control del virus IPN en su principal medio de transmisión, el agua.

\section{RESUMEN}

El virus de la necrosis pancreática infecciosa, virus IPN, es el agente causal de una enfermedad altamente contagiosa que afecta principalmente a peces jóvenes. El virus IPN se transmite mayoritariamente en forma horizontal, por lo cual la cuantificación del virus en el agua es fundamental para un adecuado manejo sanitario de la industria del salmón y del medio ambiente vecino a los sitios de cultivo. Con el fin de establecer el potencial riesgo del agua contaminada con virus IPN es necesario determinar la cantidad de virus activo mediante un procedimiento de detección con la adecuada sensibilidad para cuantificarlo en sus niveles de riesgo mínimos. Para contribuir a satisfacer esta necesidad es que se desarrolló una metodología que permite concentrar al virus desde el agua mediante la combinación de dos tipos de ultrafiltración. Uno basado en el flujo tangencial de la muestra por la superficie de 
una membrana concentradora y el otro basado en la retención de las partículas virales en la superficie de membranas de poro controlado. Se seleccionaron soluciones y condiciones de aplicación para minimizar la inactivación del virus y/o su unión a los filtros. Finalmente se establece un protocolo mediante el cual es posible concentrar mil veces al virus y con una recuperación total de la infectividad. La aplicación del método no tarda más de un día incluyendo la titulación del virus mediante la técnica de los focos fluorescentes.

\section{REFERENCIAS}

Alonso MC, J Rodríguez, JJ Borrego. 1999. Enumeration and isolation of viral particles from oligotrophic marine environments by tangential flow filtration. Int Microbiol 2, 227-232.

Cohen J, A Poinsard, R Scherrer. 1973. Physicochemical and morphological features of infectious pancreatic necrosis virus. J Gen Virol 21, 484-498.

Danovaro R, A Dell'Anno, A Trucco, M Serresi, S Vanucci. 2001. Determination of virus abundance in marine sediments. Appl Environ Microbiol 67 (3), 1384-1387.

Eliasson I. 2003a. Infectious pancreatic necrosis virus structural studies and methodology. Department of Cell and Organism Biology. PhD thesis in Microbiology. Lund, Suecia.

Eliasson I, S Sydoff, E Everitt. 2003b. Capturing ion exchangerbound infectious pancreatic necrosis virus- design and application for large volume water samples. J Virol Methods 110, 173-178.

Espinoza JC, G Farías, M Soler, J Kuznar. 1985. Identity between infectious pancreatic necrosis virus VR-299 and a Chilean isolate. Intervirology. 24, 58-60.

Espinoza JC, J Kuznar. 2002. Rapid simultaneous detection and quantitation of infectious pancreatic necrosis virus. $J$ Virol Methods 105, 81-85.

Fondo de Investigación Pesquera (FIP). 2003. Riesgos de introducción de enfermedades infectocontagiosas en salmónidos. (Informe final Proyecto FIP 2001-08).
Grinnel B, JC Leong. 1979. Recovery and concentration of infectious pancreatic necrosis (IPN) virus in water. J Fish Res Board Can 36, 1405-1408.

Maheshkumar S, SM Goyal, PP Economon. 1991a. Evaluation of a water concentration method for the detection of infectious pancreatic necrosis virus in a fish hatchery. $J$ Appl Ichthyol 7, 115-119.

Maheshkumar S, SM Goyal, B Peterson, PP Economon. 1991b. Method for the concentration of infectious pancreatic necrosis virus from hatchery water. J Virol Methods 31, 211-218.

Maheshkumar S, SM Goyal, PP Economon. 1992. Evaluation of a concentration procedure to detect infectious pancreatic necrosis virus in water. $J$ Aquat Anim Health 4, 58-62.

McAllister PE, J Bebak. 1997. Infectious pancreatic necrosis virus in the environment: relationship to effluent from aquaculture facilities. $J$ Fish Dis 20, 201-207.

Noble R. 2001. Enumeration of Viruses. En: Paul, J.H. (ed.). Marine Microbiology: Methods in Microbiology. Academic Press. Florida, USA. 30, 43-51.

Reno PW. 1999. Infectious Pancreatic Necrosis and Associated Aquatic Birnavirus. En: Woo, P.T.K., Bruno, D.W. (eds.). Fish Diseases and Disorders: Viral, Bacterial and Fungal Infectious. CABI Publishing. New York, USA. 3, 1-56.

Rodríguez Saint-Jean S, JJ Borrego, SI Pérez-Prieto. 2001. Comparative evaluation of five serological methods and RT-PCR assay for the detection of IPNV in fish. $J$ Virol Methods 97 (1-2), 23-31.

Tu K-C, R Spendlove, R Goede. 1974. Immunofluorescent cell assay of infectious pancreatic necrosis virus. Appl Microbiol 27, 579-593.

Watanabe RA, J Fryer, J Rohovec. 1988. Molecular filtration for recovery of waterborne viruses of fish. Appl Environ Microbiol 54, 1606-1609.

Wolf K. 1988. Fish viruses and fish viral diseases. Cornell University Press, Ithaca. New York and London. 